\title{
KINETIKA HIDROLISIS PATI SINGKONG MANIS (MANIHOT ESCULENTA) PADA SUHU RENDAH
}

\author{
Hargono \\ Departemen Teknik Kimia, Fakultas Teknik, Universitas Diponegoro \\ Jl. Prof.Sudharto, Tembalang, Semarang, 50275, Telp./Fax. (024) 7460058/(024) 76480675 \\ Email : hargono@che.undip.ac.id
}

\begin{abstract}
Abstrak
Singkong manis (Manihot esculenta) merupakan tanaman perdu yang dapat tumbuh di daerah tropi, seperti di Indonesia. . Kandungan karbohidrat singkong manis mencapai 90,46\% sehingga layak dikonversi menjadi gula reduksi dan etanol. Penelitian ini bertujuan untuk melakukan hidrolisis enzimatik pati singkong manis pada suhu $30^{\circ} \mathrm{C}$ sebagai alternatif pengganti hidrolisis konvensional yang membutuhkan suhu tinggi (90-125\%). Jenis enzim yang digunakan adalah granular strach hydrolyzing enzyme (GSHE) yaitu Stargen ${ }^{T M} 002$ yang merupakan enzim koktail yaitu campuran dari A. kawachi $\alpha$-amylase dari Trichorderma reesei dan glucoamylase dari A. niger. Hidrolisis enzimatis dilakukan pada substrat pati singkong manis pada konsentrasi 100, 200, 300 dan $400 \mathrm{~g} / \mathrm{L}$, konsentrasi enzim $1.5 \%$ (w/w pati), selama 24 jam, pH 4, dan suhu $30^{\circ} \mathrm{C}$. Selama hidrolisis 24 jam, kondisi terbaik dicapai pada waktu 12 jam yang menghasilkan gula reduksi masing-masing adalah 40,12; 58,32; 60,24 dan 61,34 g/L. Gula reduksi yang dihasilkan dari hidrolisis pati singkong manis pada konsentrasi diatas $200 \mathrm{~g} / \mathrm{L}$ hanya sedikit lebih besar dibandingkan gula reduksi yang dihasilkan dari hidrolisis pati singkong manis pada konsentrasi $200 \mathrm{~g} / \mathrm{L}$. Hal ini menunjukkan terjadi inhibisi substrat yang menghambat proses difusi. Parameter kinetika yaitu $V_{\text {maks }}$ dan $K_{m}$ ditentukan dengan persamaan Michaelis-Menten dan Lineweaver-Burk. Nilai $V_{m a k s}$ dan $K_{m}$ yang diperoleh dari hidrolisis ini adalah 9,074 g/L.jam, dan $K_{m}$ 104,26 g/L. Nilai Km yang kecil menunjukkan bahwa untuk mencapai proses katalitik optimal dibutuhkan konsentrasi substrat yang kecil, sehingga akan meghemat biaya proses hidrolisis.
\end{abstract}

Kata kunci: GSHE, gula reduksi, parameter kinetika, pati singkong manis, suhu rendah

\section{PENDAHULUAN}

Singkong (Manihot esculenta) atau ubi kayu merupakan tanaman pangan perdu. Sejumlah laporan telah mendukung pandangan bahwa singkong berasal dari Amerika Selatan (Clemen et al., 2010; Balagopalan et al., 1988). Allem (1994) mengemukakan pengakuan tiga sub spesies dari Manihot esculenta yaitu: Manihot esculenta esculenta, Manihot esculenta peruviana dan Manihot esculenta flabellifolia. Manihot esculenta Crantz termasuk dalam famili Euphorbiaceae dan merupakan tanaman singkong unggulan yang dibudidayakan. Famili dari tanaman ini umumnya dibagi menjadi dua kelompok utama, yaitu varietas pahit atau beracun dan varietas yang manis atau tidak beracun (Elias et al., 2004; Nye, 1991). Kadar karbohidrat pada singkong manis sebesar 90,46\% (Hapsari et al., 2013), oleh karena itu melalui proses hidrolisis enzimatik singkong manis layak dikonversi menjadi glukosa dan etanol.

Hidrolisis enzimatis pati terdiri dari 2 tahap, yakni : proses likuifikasi $\left(90-125^{\circ} \mathrm{C}\right)$ dan sakarifikasi $\left(55-65^{\circ} \mathrm{C}\right)$. Kedua proses ini merupakan proses hidrolisis konvensional. Pada proses hidrolisis pati, digunakan enzim jenis alfa-amilase dan gluko-amilase. Enzim alfaamilase yang berfungsi untuk memutus ikatan amilosa pati pada proses likuifikasi, sementara glukoamilase akan berperan pada tahap sakarifikasi untuk menguraikan pati dan menghasilkan monomer glukosa.

Dalam proses fermentasi dibutuhkan energi yang besar untuk proses pemanasan dan pendinginan. Sebesar 30 - 40\% dari total energi proses produksi etanol digunakan untuk kedua proses ini (Lee et al., 2012). Hidrolisis enzim tunggal terhadap bahan baku pati (amilum) akan menghasilkan gula reduksi yang konsentrasinya semakin besar dengan kenaikan kandungan amilum dalam bahan baku (Suresh et al., 1999).

Gohel dan Duan melakukan hidrolisis terhadap Indian broken rice dan Pearl Millet dengan variasi konsentrasi substrat 30 dan $35 \%$, diperoleh hasil gula terfermentasi untuk Indian broken rice lebih tinggi bila dibandingkan dengan Pearl Millet. Pengembangan proses hidrolisis konvensional telah dilakukan oleh banyak peneliti dengan cara menurunkan suhu hidrolisis menjadi lebih rendah $\left(50-65^{\circ} \mathrm{C}\right)$ 
menggunakan enzim campuran $\alpha$-amilase dan gluko-amilase.

Hidrolisis enzimatik pada suhu rendah memberikan peluang beberapa enzim bekerja secara sinergi dalam granula pati, sehingga tidak diperlukan lagi likuifikasi dan langkah pemasakan (cooking). Proses hidrolisis ini dapat mereduksi kebutuhan energi (Galvez, 2005). Shariffa et al. (2009) melaporkan hasil penelitian pati tapioka menggunakan campuran enzim alfa-amilase dan glukoamilase dengan temperatur $50^{\circ} \mathrm{C}$ selama 24 jam, diperoleh Dextrose equivalent maksimum $36 \%$. Uthumporn et al. (2012) melakukan hidrolisis pati jagung menggunakan campuran alfaamilase dan glukoamilase pada temperatur 30$50^{\circ} \mathrm{C}$ selama 24 jam, diperoleh kenaikan Dextrose equivalent dari 53\% menjadi 56\%.

Tujuan penelitian ini mencari data kinetika hidrolisis dan parameter kinetika dari berbagai konsentrasi pati singkong manis menggunakan granular starch hydrolyzing enzyme (GSHE) pada suhu $30^{\circ} \mathrm{C}$

\section{METODOLOGI}

\section{Singkong manis}

Singkong manis (Manihot esculenta) diperoleh dari Godean, Daerah Istimewa Yogyakarta, saat dipanen berumur 10 bulan.

\section{Ekstraksi ubi singkong}

Ubi singkong dipilih, dicuci serta dikupas kulitnya. Lalu daging ubi diparut, dicampur dengan air dan diremas-remas agar pati yang terkandung dalam perasan ubi tersebut keluar. Langkah selanjutnya adalah pemisahan pati dari campurannya dengan menyaring menggunakan kain sambil diperas menggunakan tangan sampai pati yang diinginkan semuanya terpisah dari saringan. Air dan pati yang lolos dari saringan didiamkan selama 24 jam agar pati mengendap. Selanjutnya pati dan air dipisahkan (dilimbang), dijemur untuk mengurangi kandungan airnya dengan cara dipanaskan dengan sinar matahari selama 3 hari berturut turut. Pati ubi singkong yang sudah kering (kandungan air sekitar 10\%) disimpan dalam tempat penyimpanan yang bersuhu $4^{\circ} \mathrm{C}$ pada Laboratorium Bioproses, Departemen Teknik Kimia, Fakultas Teknik Undip.

\section{Reagen kimia}

Potassium sodium tartrate tetrahydrate dan 3,5-Dinitrosalicylic acid (by Merck), $\mathrm{NaOH}$ (98\%, Merck), $\mathrm{Na}_{2} \mathrm{SO}_{3}$ (98.5\%, Merck), $\mathrm{H}_{2} \mathrm{SO}_{4}$ (98.5\%, Merck), sodium acetat buffer (Merck) and glucose $(99.5 \%$, Merck) dibeli dari SigmaAldrich Indonesia.

\section{Enzyme}

Jenis enzim yang digunakan adalah granular starch hydrolyzing enzyme (GSHE), yaitu Stargen ${ }^{T M}$ 002, merupakan campuran dari Aspergillus kawachi alfa-amylase dari Trichorderma reesei dan gluco-amylase dari Aspergillus niger yang dihasilkan oleh Genencor (Palo Alto, USA). Aktivitas enzim $570 \mathrm{GAU} / \mathrm{g}$ dan $\mathrm{pH}$ optimal 4-4,5. (Genencor,2009)

\section{Hidrolisis enzimatis}

Pati casava dibuat slury dengan konsentrasi 100, 200, 300 dan $400 \mathrm{~g} / \mathrm{L}$, pada $\mathrm{pH} 4$ dengan cara mengatur menggunakan $50 \mathrm{mM}$ sodium acetate buffer, konsentrasi enzim 1.5\% (w/w). Campuaran umpan hidrolisis diinkubasi pada $80^{\circ} \mathrm{C}$ selama 15 menit, diaduk dengan pengaduk kontinyu pada kecepatan 100 putaran per menit. Selanjutnya slury didinginkan sampai suhu 30 ${ }^{\circ} \mathrm{C}$ dan diinkubasi selama 48 jam. Secara berkala dengan interval 6 jam, sampel diambil untuk dianalisa kandungan produk gula reduksi menggunakan Spektrophotometer (UV-160A, SHIMADZU, Kyoto, Japan). Sebelum dilakukan analisis sampel terlebih dahulu dilakukan pemusingan (centrifugasi), pada 100 rpm, selama 10 menit untuk mendapatkan filtrat yang akan dianalisis gula reduksinya.

\section{Konsentrasi Substrat Mempengaruhi Kecepatan Reaksi yang Dikatalisis oleh Enzim}

Kecepatan reaksiPada konsentrasi substrat yang cukup rendah, kecepatan reaksi juga akan sangat kecil, kecepatan ini akan meningkat seiring dengan meningkatnya konsentrasi substrat. Kecepatan awal reaksi akan meningkat dengan nilai peningkatan yang semakin kecil (Copeland, 2009). Hubungan antara $\mathrm{V}_{0}$ dan [S] dinyatakan secara matematika persamaan Michaelis Menten sebagaimana ditunjukkan pada oleh persamaan 1 : 


$$
\mathrm{V}_{0}=\frac{\mathrm{V}_{\text {maks }}[\mathrm{S}]}{[\mathrm{S}]+\mathrm{K}_{\mathrm{m}}}
$$

dengan :

$$
\begin{aligned}
\mathrm{V}_{0}= & \text { kecepatan awal pada konsentrasi } \\
& \text { substrat }[\mathrm{S}] \\
\mathrm{V}_{\text {maks }}= & \text { kecepatan maksimum, yaitu } \\
& \begin{array}{l}
\text { kecepatan yang berangsur-angsur } \\
\text { dicapai pada konsentrasi substrat }
\end{array} \\
& \text { tinggi } \\
= & \text { konsentrasi awal substrat } \\
\mathrm{[S}] & \text { tetapan Michaelis-Menten enzim } \\
& \text { bagi substrat tertentu atau } \\
& \text { konsentrasi substrat yang } \\
& \text { menghasilkan setengah kecepatan } \\
& \text { maksimum }
\end{aligned}
$$

\section{Penentuan Parameter Kinetika}

Salah satu pendekatan sederhana dalam percobaan kinetika adalah untuk mengukur kecepatan reaksi mula-mula $\left(\mathrm{V}_{0}\right)$. Kecepatan reaksi mula-mula untuk setiap konsentrasi substrat ditentukan dari slop kurva pada awal reaksi. Karakteristik konstanta $\mathrm{V}_{\max }$ dan $\mathrm{K}_{\mathrm{m}}$ dapat ditentukan melalui persamaan 2 (Lineweaver-Burk, 1934). Persamaan ini merupaka hubungan antara $1 /[\mathrm{S}]$ vs $1 / \mathrm{V}_{\mathrm{o}}$. Kurve yang didapat adalah garis lurus dengan slope $=K_{m} / V_{\text {maks }}$, sedangkan intersep $=1 / \mathrm{V}_{\text {maks }}$

$$
\frac{1}{v_{0}}=\frac{\mathrm{K}_{\mathrm{m}}}{\mathrm{v}_{\max }}\left[\frac{1}{\mathrm{~s}}\right]+\frac{1}{\mathrm{v}_{\max }}
$$

\section{HASIL DAN PEMBAHASAN}

Pengaruh Konsentrasi Pati Singkong Manis (Manihot esculenta) terhadap Konsentrasi Gula Reduksi

Pengaruh konsentrasi pati singkong manis $100,200,300$ dan $400 \mathrm{~g} / \mathrm{L}$ dan pengaruh Stargen $^{\mathrm{TM}} 002$ pada konsentrasi $1,5 \%$ terhadap konsentrasi gula reduksi, ditunjukkan pada Gambar 1. Kenaikan konsentrasi pati singkong manis dari $100 \mathrm{~g} / \mathrm{L}$ ke $200 \mathrm{~g} / \mathrm{L}$, terjadi kenaikan konsentrasi gula reduksi $45,36 \%$ (dari 40,12 $\mathrm{g} / \mathrm{L}$ menjadi $58,32 \mathrm{~g} / \mathrm{L}$ ). Kenaikan konsentrasi pati dari $200 \mathrm{~g} / \mathrm{L}$ ke $300 \mathrm{~g} / \mathrm{L}$, terjadi kenaikan konsentrasi gula reduksi 3,29\% (dari 58,32 g/L menjadi 60,24 g/L), sedangkan pada kenaikan konsentrasi pati dari $300 \mathrm{~g} / \mathrm{L}$ ke $400 \mathrm{~g} / \mathrm{L}$, terjadi kenaikan konsentrasi gula reduksi $1,86 \%$ (dari 60,24 g/L menjadi 61,36 g/L).

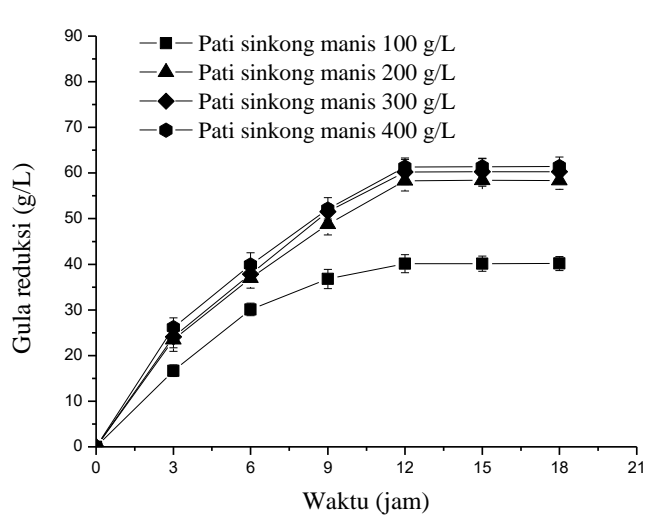

Gambar 1. Pengaruh konsentrasi pati singkong manis, terhadap konsentrasi gula reduksi menggunakan Stargen ${ }^{\mathrm{TM}} \mathbf{0 0 2}$, konsentrasi $1,5 \%(\mathrm{~b} / \mathrm{b}), \mathrm{pH} 4$, suhu $30^{\circ} \mathrm{C}$.

Berdasarkan Gambar 1 menunjukan profil kenaikan konsentrasi gula reduksi yang signifikan. Kenaikan konsentrasi gula reduksi yang tinggi dicapai pada konsentrasi pati 200 $\mathrm{g} / \mathrm{L}$. Kenaikan gula reduksi yang rendah dicapai pada konsentrasi pati diatas $200 \mathrm{~g} / \mathrm{L}$. Rendahnya peningkatan konsentrasi gula reduksi pada konsentrasi pati singkong manis diatas $200 \mathrm{gr} / \mathrm{L}$ disebabkan oleh inhibisi dari substrat. German et al. (2011) menyatakan bahwa aktivitas enzim akan meningkat seiring dengan meningkatnya konsentrasi substrat, tetapi aktivitas enzim akan menurun pada konsentrasi substrat tertentu karena adanya inhibisi dari substrat. Inhibisi substrat terjadi pada konsentrasi substrat yang tinggi.

Viskositas substrat akan semakin besar seiring dengan besarnya konsentrasi subtsrat, hal ini akan memperlambat proses difusi sehingga reaksi enzimatis akan dikontrol oleh proses difusi (diffusion limitation) (Baks et al., 2008). Pada proses hidrolisis pati, enzim mulai terinhibisi oleh substrat pada konsentrasi substrat $250 \mathrm{~g} / \mathrm{L}$ (Yankov et al., 1986). Dari hasil percobaan terlihat bahwa pada konsentrasi pati singkong manis diatas $200 \mathrm{~g} / \mathrm{L}$, konsentrasi pati singkong manis tidak berpengaruh terhadap gula reduksi. Hal ini menunjukkan bahwa pada konsentrasi pati singkong diatas $200 \mathrm{~g} / \mathrm{L}$ sudah terjadi inhibisi substrat terhadap enzim. Hal yang berbeda terlihat pada konsentrasi pati singkong manis $100 \mathrm{~g} / \mathrm{L}$ dan $200 \mathrm{~g} / \mathrm{L}$.

Konsentrasi gula reduksi yang dihasilkan pada konsentrasi substrat $100 \mathrm{~g} / \mathrm{L}$ lebih rendah dibandingkan pada konsentrasi substrat 200 g/L. Perbedaan ini terjadi karena pada konsentrasi dibawah $200 \mathrm{~g} / \mathrm{L}$ belum terjadi inhibisi substrat sehingga peningkatan 
konsentrasi substrat akan menaikkan konsentrasi gula reduksi. Ruiz et al. (2011) telah melakukan kajian tentang proses hidrolisis pati singkong menggunakan Stargen ${ }^{\mathrm{TM}} 001$ dan menyimpulkan bahwa aktivitas enzim akan meningkat seiring dengan meningkatnya konsentrasi pati, akan tetapi aktivitas enzim akan menurun pada konsentrasi pati diatas 250 $\mathrm{g} / \mathrm{L}$.

\section{Pengaruh konsentrasi awal substrat terhadapap kecepatan awal}

Sebagaimana ditunjukkan pada Gambar 2, hubungan kecepatan awal enzim dengan konsentrasi pati singkong manis sering kali diasumsikan sebagai bentuk kinetika saturasi. Aktivitas awal enzim meningkat dengan meningkatnya konsentrasi awal pati singkong awal. Kecepatan awal enzim meningkat dari 5,56 menjadi 8,64 g/L.jam (untuk konsentrasi pati singkong $300 \mathrm{~g} / \mathrm{L}$ ), selanjutnya pada konsentrasi pati singkong $400 \mathrm{~g} / \mathrm{L}$, mencapai hampir konstan, yaitu 8,71 g/L.jam. Hal ini menunjukkan bahwa pada konsentrtasi pati yang besar berakibat viskositas slury menjadi besar sehingga akan menghambat proses difusi) (Baks et al., 2008).

\section{Penentuan Parameter Kinetika $\mathbf{K}_{\mathbf{m}}$ dan $\mathbf{V}_{\text {maks }}$}

Parameter kinetika, yaitu $\mathrm{K}_{\mathrm{m}}$ dan $\mathrm{V}_{\text {maks }}$ ditentukan dengan persamaan 2. Selanjutnya hubungan antara $1 / \mathrm{V}_{0}$ dan $1 /[\mathrm{S}]$ ditunjukkan pada Gambar 3. Menurut persamaan 2, nilai $\mathrm{K}_{\mathrm{m}} / \mathrm{V}_{\text {maks }}$ merupakan slope, sedangkan $1 / \mathrm{V}_{\text {maks }}$ adalah intersep dari kurve garis lurus seperti yang ditunjukkan pada Gambar 3. Hasil pembacaan dari kurve diperoleh nilai $\mathrm{V}_{\text {maks }}$ 9,074 g/L.jam, sedangkan $K_{m} \quad 104,26 \mathrm{~g} / \mathrm{L}$. Nilai $\mathrm{K}_{\mathrm{m}}$ menunjukkan bahwa untuk mencapai proses katalitik optimal dibutuhkan konsentrasi substrat yang optimal pula (Michaelis-Menten, 1913) dan Lehninger, 1982). Nilai $V_{\text {maks }}$ menunjukkan kecepatan reaksi mencapai maksimum meskipun konsentrasi substrat bertambah.

Pada kondisi tersebut enzim telah mencapai kondisi jenuh oleh substratnya sehingga tidak dapat berfungsi dengan baik Lehninger, 1982). Hasil ini similar dengan penelitian yang dilakukan Hargono et al. (2017) tentang hidrolisis pati singkong pahit dan pati gadung, diperoleh nilai $\mathrm{Km}$ dan $\mathrm{V}_{\text {maks }}$ adalah 141,64 ; $140.84 \mathrm{~g} / \mathrm{L}$ dan 13,$33 ; 7,46 \mathrm{~g} / \mathrm{L}$.jam.

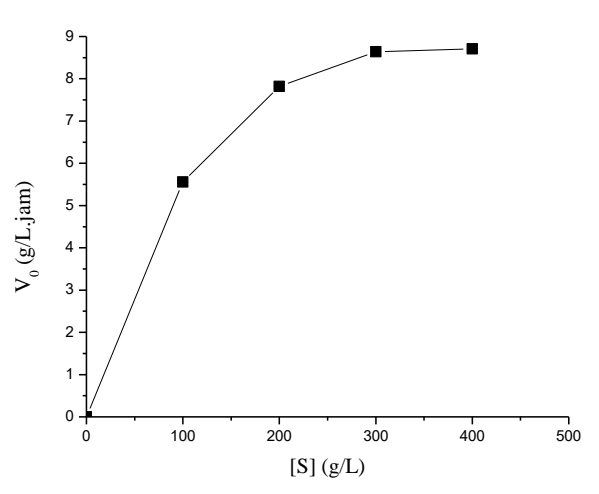

Gambar 2. Pengaruh konsentrasi awal pati singkong terhadap kecepatan aktivitas awal enzim pada konsentrasi enzim 1,5\%, pH 4 dan $30^{\circ} \mathrm{C}$.

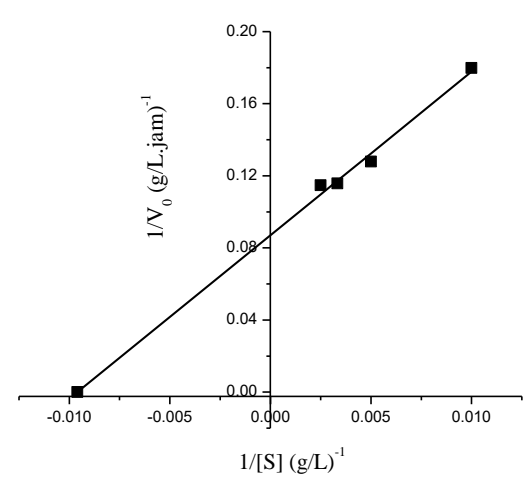

Gambar 3. Plot Lineweaver-Burk untuk berbagai konsentrasi pati singkong manis terhadap kecepatan aktivitas awal enzim

\section{KESIMPULAN}

Hidrolisis enzimatis pati singkong manis (Manihot escullenta) pada konsentrasi $200 \mathrm{~g} / \mathrm{L}$ menggunakan Stargen ${ }^{\mathrm{TM}} 002$ pada konsentrasi $1,5 \%, \mathrm{pH} 4$ dan $30^{\circ} \mathrm{C}$ selama 12 jam merupakan kondisi terbaik. Gula reduksi yang dihasilkan pada kondisi ini adalah 58,32 g/L. Pada konsentrasi pati diatas $200 \mathrm{~g} / \mathrm{L}(300-400 \mathrm{~g} / \mathrm{L})$ terjadi inhibisi substrat yang akan menghambat proses difusi. Pada konsentrasi pati singkong manis 100-400 g/L diperoleh nilai $V_{\text {maks }} 9,074$ $\mathrm{g} / \mathrm{L}$.jam, sedangkan $\mathrm{K}_{\mathrm{m}}$ 104,26 g/L.

\section{DAFTAR PUSTAKA}

Allem, A.C., (1994), The origin of Manihot esculenta Crantz (Euphorbiaceae). Genetic Resources and Crop Evolution, 41 (3), pp. 133-150.

Baks, T., Bruins, M. E., Janssen, A. E. M., Boom, R. M., (2008). Effect of Pressure 
and Temperature on the Gelatinization of Starch at Various Starch Concentrations. Biomacromolecules. 9(1), pp. 296-304.

Balagopalan, C., Padmaja, G., Nanda, S.K., Moorthy, S.N., (1988). Cassava in Food, Feed, and Industry. CRC Press, Inc. Boca Raton, Florida.

Clement, C.R., de Cristo, A.M., Coppens D. E.G., Alves, P.A., Picanço.R.D., (2010), Origin and domestication of native Amazonian crops. Diversity, 2 (1), pp. 72-106.

Copeland, Robert A., (2000). ENZYMES A Practical Introduction to Structure Mechanism, and Data Analysis. Second Edition. New York: A John Wiley \& Sons, Inc.

Elias, M., Mühlen, G.S., McKey, D., Roa, A.C., Tohme, J., (2004), Genetic diversity of traditional South American landraces of cassava (Manihot esculenta Crantz): an analysis using microsatellites. Econ Bot, 58 (2): pp. 242-256.

Galvez, A., (2005), Analyzing cold enzyme starch hydrolysis technology in new ethanol plant design, Ethanol Producer. 11, pp. 58-60.

Genencor. STARGENTM 002. (2009). Granular starch hydrolyzing enzyme for ethanol production.

German, D.P., Weintraub, M.N., Grandy, A.S., Lauber,C.,L.,Rinkes, Z.L., Allison, S.D., (2011). Optimization of hydrolytic and oxidative enzyme methods for ecosystem studies. Soil Biology \& Biochemistry, 43, pp. 13871397.

Gohel, V., Duan, G., Maisuria, V. (2013). Impact of an acid fungal protease in high gravityfermentation for ethanol production using indian sorghum as a feedstock, Biotechnology Progress, 29, pp.329-336.

Hapsari, M. A. dan Pramashinta, A. (2013). Pembuatan Bioetanol dari Singkong Karet (Manihot glaziovii) sebagai Upaya Mempercepat Konversi Minyak Tanah ke Bahan Bakar Nabati. Jurnal Teknologi Kimia dan Industr. 2(2), pp. 240-245.

Hargono, H., Jos, B., Kumoro, A. C. (2017). Kinetics of the enzymatic hydrolysis of sweet cassava starch and bitter cassava flour and gadung (Dioscorea hispida Dennst) flour at low temperature. Bulletin Chemical Reaction Engineering \&. Catalytic, 12 (2), pp.256-262.

Lee, W.S., Chen, I.C., Chang, C.H., Yang, S.S. (2012). Bioethanol production from sweetpotato by co-immobilization of saccharolytic molds and Saccharomyces cerevisiae. Renewable Energy, 39, pp. 216-222.

Lehninger AL. Principles of Biochemistry. $5^{\text {th }}$. New York: W.H. Freeman. 1982.

Lineweaver H, Burk D. (1934). The determination of enzyme dissociation constants. Journal of the American Chemical Society, 56, pp. 658-666.

Michaelis, L., and Menten, M. (1913) Die Kinetik der Invertinwirkung, Biochem.Z., 49, pp. 333-369.

Nye, M.M. (1991). The Mis-measure of manioc (Manihot esculenta, Euphorbiaceae) Economic Journal, 45 (1), pp. 47-57.

Botany

Shariffa, Y. N., Karim, Fazilah, and Zaidul, I. S. M. (2009). Enzymatic hydrolysis of granular native and mildly heat-treated tapioca and sweet potato starches at subgelatinization suhue. Food Hydrocolloid, 23(2), pp.434-440.

Suresh, K., Kiransree, N., and Venkateswar Rao, L. (1999). Production of ethanol by raw starch hydrolysis and fermentation of damaged grains of wheat and sorghum. Bioprocess Engineering, 21(2), pp. 165172.

Uthumporn, U., Shariffa, Y.N., Karim, A.A. (2012). Hydrolysis of native and heattreated starches at sub-gelatinization suhue using granular starch hydrolyzing enzyme. Applied Biochemistry and Biotechnology, 166(5), pp. 1167-1182

Yankov, D., Dobreva, E., Beschkov, Emanuilova. (1986). Study of optimum conditions and kinetics of starch hydrolysis by means of thermostable $\alpha$ amylase. Enzyme and Microbiol Technology, 8, pp. 665-667. 